\title{
PERILAKU INDIVIDU DALAM MENUNJANG EFEKTIVITAS ORGANISASI
}

\author{
Oleh: Sugi Rahayu \\ sugirahayu@uny.ac.id
}

\section{Abstrak}

Manusia merupakan sumberdaya yang paling penting dalam kehidupan organisasi, sehingga memertukan penanganan yang tepat. Sumberdaya manusia yang berfokus pada individu yang menjadi anggota organisasi memiliki pandangan, tujuan, kebutuhan dan kemampuan yang berbeda, sehingga memerikan perlakuan berbeda agar dapat diarahkan pada satu ikatan, yaitu keterikatan terhadap organisasi. Perbedaan karakteristik ini membawa pertbedaan perilaku. Perilaku yang mereka tunjukkan tersebut tidak selamanya relevan dengan upaya pencapaian tujuan organisasi. Dengan demikian kebijakan organisasi harus disesuaikan atau diupayakan agar perilaku anggota sesuai dengan kebijakan yang ditempuh. Lebih dari itu pimpinan dapat memanfaatkan informasi tentang berbagai perbedaan tersebut untuk ineningkatkan kejasama di antara para anggota dalam kelompok. Dengan demikian pemahaman terhadap perilaku individu bagi seorang pimpinan adalah merupakan satu hal yang sangat penting. Untuk itu The Heart and The Process of Organizational Behavior hans diterapkan sehingga tercipta Quality Working Life dalam Organisasi yang bersangkutan

\section{Pendahuluan}

Dalam suatu organisasi, manusia merupakan salah satu sumberdaya yang memiliki karakteristik yang khas yang berbeda dengan sumberdaya lainnya. Sumberdaya manusia, baik yang menggerakkan maupun yang digerakkan, memiliki sifat dinamis dan berkemampuan untuk berkembang. Hal tersebut menjadikan manusia merupakan sumberdaya yang paling penting dalam kehidupan organisasi, yang apabila ditangani secara tepat akan merupakan modal yang tak terhingga nilainya dalam upaya mencapai tujuan organisasi. Sebaliknya jika tidak ditangani dengan baik akan dapat membahayakan eksistensi organisasi.

Dengan memberikan penanganan yang tepat, kemampuan dan potensi sumberdaya manusia dapat 
dimanfaatkan secara optimal dan dapat dilipatgandakan. Di sisi lain, manusia sebagai individu juga ingin tumbuh dan mengembangkan diri. Sehubungan dengan hal tersebut perlu adanya keselarasan antara kepentingan individu dengan kepentingan organisasi, sehingga akan tercipta suatu keseimbangan antara kepentingan individu dengan tujuan organisasi yang telah ditentukan. Menurut Manullang, Organisasi merupakan kumpulan orangorang yang bekerjasama untuk mengerjakan suatu kegiatan yang telah direncanakan untuk mencapai suatu tujuan (1982:69). Suatu organisasi memiliki kesempatan untuk bertahan dan maju apabila organisasi itu memiliki orangorang yang tepat.

Mengingat besamya peranan sumberdaya manusia dalam suatu organisasi, maka perlu adanya perhatian yang besar dari pimpinan untuk memahami hakikat manusia, karena saiah satu tugas dan fungsinya yang sangat rumit adalah mengkoordinasikan manusia-manusia yang dipimpinnya ke arah pen-capaian tujuan organisasi. Prestasi kerja dan kepuasan kerja sebagai ujud perilaku individu dapat berbeda antara organisasi yang satu dengan yang lain. Mengapa hal ini terjadi? Untuk itu periu dikaji: Seberapa jauh perilaku individu mempengaruhi Efektivitas Organisasi?

\section{Efektivitas Organisasi}

Efektivitas organisasi dipengaruhi oleh banyak faktor. Menurut Steers (1985) ada empat faktor yang berhubungan dengan efektivitas organisasi, yaitu: (1) karakteristik organisasi, (2) karakteristik lingkungan, (3) karakteristik pekerja, dan (4) kebijaksanaan dan praktik manajemen. Selanjutnya dijelaskan bahwa, karakteristik organisasi terutama berkenaan dengan struktur dan teknologi yang digunakan di dalam Organisasi. Dimensi teknologi memperlihatkan proses mekanis atau intelektual lewat mana organisasi mengubah masukan menjadi keluaran dalam mencapai tujuan organisasi. Steers menyatukan teknologi dengan struktur karena bukti menunjukkan bahwa variasi teknologi berinteraksi dengan struktur dalam pengaruhnya terhadap keberhasilan organisasi.

Karakteristik lingkungan organisasi dapat dibedakan menjadi: (1) lingkungan intemal dan (2) lingkungan eksternal. Pembahasan pada lingkungan intemal berfokus pada iklim yang meliputi macammacam atribut lingkungan kerja sehingga unit analisisnya mikro yang membahas tentang karakteristik pekerja, yaitu moral kerja, kepuasan kerja produktivitas kerja (prestasi individu). Lingkungan eksternal berfokus pada hubungan antara organisasi dengan lingkungan luar dimana organisasi 
hidup. Implikasinya adalah pembahasannya bersifat makro dengan unit analisis lingkungan luar.

Karakteristik pekerja, berfokus pada individu yang menjadi anggota organisasi sehingga kajiannya banyak diarahkan pada bagaimana memperlakukan individu yang menunjukkan adanya perbedaan pandangan, tujuan, kebutuhan dan kemampuan kemudian diarahkan pada satu ikatan, yaitu keterikatan terhadap organisasi (Steers, 1985: 10). Sedangkan Kebijaksanaan dan Praktik manajemen merupakan mekanisme yang ditempuh manajer untuk meningkatkan efektivitas organisasi, yang mencakup penentuan tujuan, pencarian dan pemanfaatan sumberdaya, penciptaan lingkungan yang merangsang anggota untuk berprestasi, pengambilan keputusan dsb.

Berdasarkan uraian di atas dan permasalahan yang akan dipecahkan dalam tulisan ini maka pembahasan lebih menitik beratkan unit analisisnya pada individu, baik pegawai maupun pimpinan dan lingkungan internal organisasi. Individu sebagai anggota organisasi merupakan faktor yang pengaruhnya terhadap efektivitas organisasi cukup besar, bahkan mungkin yang paling besar. Sehingga perilaku individu mendasari perilaku organisasi.

Miftah Thoha menyatakan bahwa perilaku adalah fungsi dari interaksi antara individu dengan lingkungan atau dirumuskan sebagai:

$$
\begin{aligned}
& P=f(I, L), \text { dimana: } \\
& P=P \text { erilaku } \\
& f=\text { fungsi } \\
& I=\text { Individu } \\
& L=\text { Lingkungan }(1995: 30) .
\end{aligned}
$$

Perilaku individu dapat merupakan dukungan yang sangat berarti bagi pencapaian efektivitas organisasi, tetapi dapat pula merupakan hambatan yang sanggup mengurangi bahkan menggagalkan efektivitas organisasi. Satu hal yang lazim pada setiap organisasi ialah bahwa masingmasing individu memiliki karakteristik tertentu yang tidak selalu sama dengan karakteristik individu yang lain. Karakteristik individu tersebut meliputi: ketrampilan, pengetahuan, kecakapan, sikap, motivasi dan stres.

Perbedaan karakteristik ini membawa perbedaan perilaku. Perilaku yang mereka tunjukkan tersebut tidak selamanya relevan dengan upaya pencapaian tujuan organisasi. Kecuali itu setiap anggota mempunyai tujuan pribadi yang tidak selamanya sinkron dengan tujuan organisasi. Secara langsung maupun tidak, setiap anggota tentu berupaya mencapai tujuan pribadinya. Konsekuensinya, perilaku yang mereka tunjukkan pun dapat berbedabeda satu dengan yang lain. 
Semuanya itu berpengaruh terhadap efektivitas organisasi.

Dalam rangka meningkatkan efektivitas organisasi, pimpinan harus mengenali adanya perbedaan karakteristik individu dan perbedaan tujuan masingmasing anggotanya. Dengan demikian kebijakan organisasi yang ditempuhnya dapat disesuaikan atau sebaliknya mengupayakan agar perilaku anggota sesuai dengan kebijakan yang ditempuh. Lebih dari itu pimpinan dapat memanfaatkan informasi tentang berbagai perbedaan tersebut untuk meningkatkan kerjasama di antara para anggota dalam kelompok. Dengan demikian pemahaman terhadap perilaku individu bagi seorang pimpinan adalah merupakan satu hal yang sangat penting. Perilaku individu dipengaruhi oleh sekurang-kurangnya empat faktor, yaitu: persepsi, sikap, nilainilai dan motivasi. Keempat faktor tersebut akan berpengaruh terhadap efektivitas (kinerja) individu dan ini akan menumbuhkan kepuasan kerja pegawai tersebut.

Dalam kenyataannya masingmasing individu tidak bekerja sendirian melainkan berinteraksi satu sama lain atau berada dalam kelompok. Dengan demikian akan terjadi perilaku kelompok. Interaksi antar individu atau perilaku antar pribadi dipengaruhi oleh sistem pribadi, konsep diri, kebutuhan dan orientasi antar pribadi masing- masing. Gabungan tingkah laku antar pribadi akan membentuk perilaku kelompok. Selain itu, perilaku kelompok dipengaruhi juga oleh faktor-faktor: latar belakang, perilaku yang diharapkan, dan perilaku yang sebenamya muncul. Output perilaku kelompok berupa produktivitas, kepuasan, dan pengembangan individu. Karena pada kenyataannya tiaptiap kelompok dalam sebuah organisasi tidak berdiri sendiri melainkan berinteraksi dengan kelompok lain, maka akan terjadi proses saling pengaruh antara kelompok tertentu dengan kelompok yang lain. Hubungan antara kelompok itu dipengaruhi juga oleh kekuasaan, tujuan, dan nilai-nilai yang dianut oleh setiap kolompok. Sampai pada level ini, betapa rumitnya perilaku anggota yang terjadi dalam suatu organisasi. Selanjutnya pada level organisasi, terutama dipengaruhi oleh pimpinan atau manajer organisasi yang bersangkutan. Gaya kepemimpinan yang diterapkan oleh pemimpin memainkan peranan penting. Cara-cara pemimpin berkomunikasi dengan anggota dan menangani perubahan serta konflik yang timbul akan menentukan bentuk perilaku organisasi. Kalau output perilaku individu adalah efektivitas individu dan output perilaku kelompok adalah produktivitas (prestasi kerja), kepuasan dan pengembangan individu, maka output perilaku 
organisasi adalah iklim kerja dan efektivitas organisasi.

\section{Peranan The Heart and The Process of Organizational Beha- vior}

Perbedaan prestasi dan kepuasan kerja pegawai antara berbagai organisasi pertu ditelusuri penyebabnya. Untuk itu perlu dianalisis peranan The Heart and The Process of Organizational Behavior. Membahas The Heart of Organizational Behavior menyangkut bagaimana mengelola individu yang ada dalam organisasi yang mempunyai perbedaan-perbedaan dan bagaimana menciptakan lingkungan kerja yang berkualitas. Untuk itu lingkungan keja yang berkualitas (Quality Working Life) perlu diciptakan, yaitu dengan: (a) Partisipasi dalam pembuatan keputusan (Participationin decision making). Nampaknya pegawai menyadari dan memahami problem yang dihadapi organisasinya, tertarik dan memandang penting problem tersebut. (b) Kondisi Kerja (working condition). Aspek fisik organisasi di mana para pegawai bekerja membuat mereka kerasan dan ditunjang oleh peralatan yang memadai sehingga mendorong mereka bekerja giat. (c) Budaya Organisasi (The Cuiture of the Organization), Orangorang yang tergabung dalam organisasi saling mendorong agar dapat menyatu dalam budaya organisasi. (d) Program Pengem- bangan Karier (Career development program). Kompetisi yang sehat dan dipikirkannya promosi dapat menumbuhkan kegairahan kerja pegawai sehingga mereka mau bekerja keras. (e) Hubungan antar pribadi dan antar kelompok (Interpersonal and intergroup relations) perlu dikoordinasikan dengan baik dan tidak menutup diri. (f) Gaya Kepemimpinan (Leadership style), yaitu ciri seorang pemimpin melakukan kegiatannya dalam membimbing, mengarahkan, mempengaruhi dan para pengikutnya dalam rangka mencapai tujuan. (g) Tingkat stress yang dialami pegawai (The Degree of stress experienced by employees). Quality Working Life merupakan sasaran utama The Heart of Organizational Behavior, ini berarti menyangkut masalah motivasi dan kepemimpinan dalam organisasi.

Disadari atau tidak setiap manusia bekerja karena mempunyai motivasi, yaitu (1) karena dia ingin mendapat penghasilan demi kelangsungan hidupnya (who does not work does not eat), (2) peningkatan status (work oriented society), dan (3) bekerja sebagai kegiatan yang menggairahkan/menyenangkan (enjoying their life). Motivasi merupakan fungsi dari motif, harapan dan insentif. Sedangkan kepemimpinan merupakan fungsi dari pemimpin, pengikut dan situasi. Kepemimpinan adalah kemampuan untuk mempengaruhi dan mengarahkan orang 
lain atau bawahan agar mau bekerja sama untuk mencapai tujuan organisasi. Untuk itu setiap pemimpin harus mampu memberikan keyakinan kepada para bawahan balnwa tujuan mereka dapat dicapai melalui tujuan organisasi. Dengan demikian seorang pemimpin hendaknya mampu menggerakkan orangorang yang punya kepentingan berbeda itu dalam lingkungan kerja yang berkualitas.

Motivasi merupakan subyek yang penting bagi seorang pemimpin, karena menurut definisinya, pemimpin harus bekerja melalui orang lain. Oleh karena itu dia harus memahami perilaku bawahan, agar dapat mempengaruhinya untuk bokerja sesuai dengan apa yang diinginkan oleh organisasi. Motivasi dibedakan menjadi motivasi intemal dan motivasi ekstemal. Dalam kaitannya dengan Quality Working Life, maka tugas seorang pemimpin untuk mencari dan memikirkan serta melaksanakan cara memotivasi bawahan secara efektif. Dalam hal ini G.R.Terry mengemukakan cara tersebut, yaitu: (1) percaya pada diri sendiri dan pada orang lain; (2) buatlah contoh yang baik; (3) tempatkan pegawai pada tempat yang tepat; (4) tekankanlah partisipasi; (5) berikan informasi yang cukup; (6) berilah imbalan dan perangsang yang sesuai; (7) kenali hasilhasil yang dicapai, dihargai dan diberi pujian; (8) tingkatkan rasa bersatu;
(9) berilah informasi tentang pekerjaan itu sendiri; (10) beri kesempatan untuk memperoleh jaminan pekerjaan; (11) manfaatkan rasa takut dengan bijaksana (1980: 107).

Pada setiap organisasi, hal tersebut harus mendapatkan perhatian yang serius artinya manusia (pegawai) dianggap lebih penting daripada pekerjaan agar pegawai termotivasi bekerja karena merasa diterima di lingkungan kerja, dan kelompok dapat menerima pegawai. The Process of Organizational Behavior mencakup komunikasi, pembuatan keputusan dan desain organisasi. Komunikasi merupakan suatu aktivitas pemindahan informasi dari seseorang kepada seseorang yang lain, melalui isyaratisyarat, tanda-tanda atau simbolsimbol dengan bahasa yang dapat dimengerti. Komunikasi dapat bersifat horisontal maupun vertikal.

Sebagai aktivitas, komunikasi administrasi dapat berupa pemberian petunjuk, keterangan umum, tegoran, pujian, perintah, laporan, penerimaan keluhan, pendapat, saran, pelaksanaan ulang maupun penyelenggaraan rapat dan pertemuan. Komunikasi merupakan salah satu kekuatan utama organisasi. Oleh karena itu, komunikasi dalam organisasi harus berjalan efektif atau lancar. Kelancaran komunikasi tergantung kepada: (1) kesamaan persepsi, pola atau kerangka pemikiran; (2) persamaan bahasa; 
(3) kejelasan pesan; (4) sarana yang tepat dalam penyampaian pesan; (5) pemilihan waktu atau saat yang tepat; (6) adanya persuasi; (7) adanya itikad baik; (8) adanya tenggang rasa.

Dalam kenyataannya, komunikasi tidak selalu lancar. Hambatan dari komunikasi yang efektif/lancar tidak saja disebabkan oleh masingmasing individu yang memiliki nilai, latar belakang sejarah dan tradisi, tetapi juga disebabkan oleh hambatan semantik, berteletele kalimatnya, jarak yang jauh, orangorang yang terlibat, kepentingan-kepentingan. Dalam organisasi komunikasi yang efektif merupakan prasyarat terbinanya kerjasama yang baik untuk mencapai tujuan organisasi. Menurut Reitz (1981), komunikasi organisasi berfungsi sebagai alat: (1) untuk menyampaikan informasi kepada seluruh anggota dalam rangka pelaksanaan fungsi dan tugasnya masingmasing; (2) meme-rintah atau memberikan instruksi, lewat komunikasi seorang pimpinan dapat meminta secara resmi kepada bawahan untuk melaksanakan atau tidak melaksanakan aktivitas tertentu dalam rangka pencapaian tujuan organisasi; (3) mempenganuhi atau melakukan persuasi ialah penggunaan persuasi untuk mengajak pihak lain mengikuti kehendak orang lain; (4) penggunaan komunikasi untuk menyatukan tindakan ber- bagai pihak untuk kepentingan koordinasi.

Proses kehidupan organisasi diwamai oleh proses pengambilan keputusan. Pengambilan keputusan ialah proses pemilihan di antara berbagai alternatif yang tersedia atau proses pemikiran dan tindakan yang menghasilkan pilinan tingkah laku. Pada sebuah organisasi, peran pengambilan keputusan sangat penting sebab berpengaruh terhadap seluruh kegiatan yang dilaksanakan. Menurut Simon, pengambilan keputusan merupakan fungsi yang paling mendasar bagi seorang manajer (1985: 405).

Untuk memudahkan proses komunikasi dan pengambilan keputusan diperlukan struktur organisasi. Struktur ini menentukan perilaku dan hubungan sosial antar anggota. Struktur memberikan kerangka kerja yang pasti dan oleh karenanya memungkinkan organisasi berjalan dalam kondisi yang relatif stabil, karena melalui struktur dapat diketahui kedudukan masing-masing anggota dalam jenjang organisasi.

Berdasarkan analisis di atas, dapat disimpulkan The Heart and Process of Organizational Behavior mempunyai peranan yang sangat penting dalam mencapai efektivitas organisasi. 
Pengaruh moral, prestasi kerja dan kepuasan kerja terhadap efektivitas atau produktivitas kerja

Moral adalah suatu sikap pikir dan kekuatan emosi yang dapat mempengaruhi disiplin, antusiasme, inisiatif, dan aspekaspek keberhasilan lainnya (Kuncorohadi, 1986: 7). Dengan demikian moral kerja terletak dalam pikiran, sikap dan emosi seseorang pegawai yang diwujudkan dalam reaksi dan perilakunya. Moral kerja pegawai biasanya akan nampak dalam perilaku kerja untuk melaksanakan tugas pekerjaannya. Karena itulah moral kerja akan menumbuhkan semangat kerja dan lebih lanjut mempengaruhi efektivitas atau produktivitas kerja. Dalam pengertian ini moral tidak diartikan sebagai moral yang baik atau buruk, tetapi moral yang tinggi dan rendah. Moral yang tinggi adalah suatu keadaan persatuan perasaan (sense of belong ingness) dan persatuan tujuan (sense of unity command), yaitu semangat yang menunjukkan kesetiaan, antusiasme, bangga dalam pekerjaan dan kesungguhan melakukan tugas.

Pegawai yang bermoral tinggi akan menunjukkan rasa tanggungjawab, disiplin kerja yang tinggi, dan lebih mengutamakan kepentingan organisasi daripada kepentingannya sendiri. Oleh karena itu upaya penciptaan kondisi yang mendukung tumbuhnya moral kerja yang tinggi perlu dilakukan oleh pimpinan, misalnya dengan memberikan perla-kuan yang adil, memperhatikan nasib anak buah, meningkatkan mutu, dan bertindak tegas terhadap pegawai yang melakukan kesalahan dan memberikan pujian yang mereka berhasil. Pegawai yang kepentingannya dilayani secara layak oleh organisasi, maka hal ini akan meningkatkan sikap pikir dan emosinya menjadi sikap terpuji.

Sebaliknya pegawai yang tak terlayani dengan layak, maka sikap pikir dan emosinya akan rendah dan menjadi sikap buruk yang akan merugikan organisasi. Jadi moral berkembang dari kepuasan bersama baik kepentingan individu dari seluruh pegawai maupun kepentingan organisasi.

Prestasi kerja adalah sesuatu yang dikerjakan atau produk/jasa yang dihasilkan atau diberikan seseorang atau sekelompok orang (Agus Dharma, 1985: 3). Seorang pegawai yang memiliki tingkat prestasi kerja tinggi dikategorikan sebagai pegawai yang produktif dan sebaliknya pegawai yang rendah prestasi kerjanya dikategorikan tidak produktif.

Dalam melaksanakan tugas pekerjaannya, seorang pegawai tidak akan terlepas dari lingkungan di mana mereka bekerja. Keterkaitan dengan lingkungan tersebut dapat berupa penyesuaian diri de- 
ngan lingkungannya, tetapi karena manusia memiliki sifat dinamis dan kemampuan untuk mengubah lingkungan agar sesuai dengan dirinya, maka manusia mampu mengubah lingkungan yang ada. Demikian pula kondisi organisasi yang melingkupi pegawai dalam melaksanakan tugas pekerjaan akan mempengaruhi perilaku kerjanya yang terwujud dalam prestasi kerja. Kondisi kerja ini menyangkut ruangan, peralatan dan mesinmesin kantor yang merupakan alat bantu bagi pekerjaan pegawai untuk mencapai prestasi kejjanya. Pada waktu tertentu prestasi kerja pegawai perlu dinilai. Penilaian prestasi kerja akan berguna bagi pegawai maupun bagi lembaga. Bagi pegawai, penilaian prestasi kerja akan merupakan penghargaan dan pengakuan terhadap eksistensi dan kemampuan kejanya. Sedangkan Bagi lembaga penilaian prestasi kerja dapat digunakan sebagai kriteria dalam menyeleksi pegawai untuk kenaikan pangkat, jabatan maupun gaji secara bijaksana. Informasi dari hasil penilaian juga dapat dijadikan pedoman untuk pengangkatan pegawai dalam jabatan atau tanggung jawab tertentu. Dengan demikian prestasi kerja dapat mempengaruhi produktivitas kerja mereka, yang selanjutnya akan mempengaruhi efektivitas organisasi.

Kepuasan kerja adalah perasaan senang atau tidak senang dari karyawan terhadap pekerjaan atau situasi lingkungannya. Kalau karyawan senang terhadap pekerjaannya, maka setiap pekerjaan yang diberikan kepadanya akan dikerjakan dengan sunggihsungguh. Tentunya ini akan berpengaruh temadap produktivitas kerjanya. Hal tersebut sesuai dengan penciapat Winkel (1989) bahwa seseorang yang mempunyai kepuasan keria akan berusaha menyelesaikan tugastugas dalam pekerjaannya sebaik mungkin, tidak asat selesai saja sehingga turut mempengaruhi hasil kerjanya. Organisasi yang ingin berhasil harus memperhatikan masalah kepuasan kerja dari para pegawainya. Kepuasan kerja dapat dilihat sebagai hasil interaksi antara manusia dengan pekerjaannya atau lingkungan kerjanya. Kepuasan kerja bersifat individual. Banyak faktor yang mempengaruht kepuasan kerja, yaitu: (1) kinerja, (2) umur, (3) kualitas pengawasan, (4) hubungan interpersonal, (5) gaji dan kondisi kerja/pekerjaan, (6) kemudahan berkomunikasi, (7) status pekerjaan/ posisi (karier), dan (8) isi pekerjaan. Kepuasan kerja timbul karena terpenuhinya kebutuhan pegawai oleh aspek-aspek pekerjaannya. Kepuasan kerja dapat menambah gairah kerja dan ini akan berpengaruh terhadap produktivitas kerja.

Berdasarkan analisis tersebut di atas dapat disimpulkan bahwa moral, prestasi dan kepuasan kerja 
secara langsung mempengaruhi efektivitas atau produktivitas kerja.

\section{Kesimpulan}

Dari telaah yang telah dilakukan, dapat disimpulkan bahwa perilaku individu dalam organisasi, baik yang digerakkan (yang dipimpin) maupun yang menggerakkan (pemimpin) mempunyai peranan yang sangat menentukan bagi keberhasilan organisasi dalam mencapai tujuannya. Oleh karenanya, dalam organisasi hal-hal yang berkaitan dengan perilaku individu, seperti: moral kerja, prestasi kerja dan kepuasan kerja harus mendapatkan perhatian yang serius. Untuk itu The Heart and The Process of Organizational Behavior harus diterapkan sehingga tercipta Quality Working Life dalam Organisasi yang bersangkutan.

\section{Daftar Pustaka}

Agus Dharma. 1985. Manajemen Prestasi Kerja. Jakarta: CV Rajawali.

Armstrong, Michael. 1990. Manajemen Sumberdaya Manusia. Jakarta: Gramedia.

Gibson, James L., et.al, 1988. Organization, Structure and Process. Plano: Business Publications, Ltd.

Kuncorohadi. 1986. Pendidikan Pegawai Negeni Moral dan
Sikap. Semarang: Fisipol Undip.

Luthans, Fred. 1992. Organizational Behavior. New York; McGraw Hill Book Co.

Manullang, M. 1982. Manajemen Personalia. Jakarta: Ghalia indonesia.

Milton, Charles R. 1981. Human Behavior in Organization. Englewood Cliffs: Prentice Hall Inc.

Reitz, J. 1981. Behavior in Organization. Homewood: Richard D. Inwin Inc.

Steers, R.M. 1995. Efektivitas Organisasi. Terjemahan M. Jamin. Jakarta: Erlangga.

Terry, George R. 1980. Motivasi dan Organisasi Perkantoran. Jakarta: ANS Sunggun Bersaudara.

Thoha, Miftah. 1996. Penilaku Organisasi: Konsep Dasar dan Aplikasinya. Jakarta: PT RajaGrafindo Persada.

\section{Boldata Penulis}

Sugi Rahayu, adalah staf pengajar pada Program Studi Pendidikan Administrasi Perkantoran, Fakultas Ilmu Sosial Universitas Negeri Yogyakarta. 